\title{
ВЛИЯНИЕ СИСТЕМ УДОБРЕНИЙ НА УРОЖАЙНОСТЬ И КАЧЕСТВО ЯРОВОЙ ПШЕНИЦЫ
}

\author{
Н.П. Баушева (фото) \\ старший преподаватель кафедры экологии \\ И.Д. Халистова \\ к.т.н., доцент кафедры экологии \\ ФГБОУ ВО Ярославская ГСХА, г. Ярославль
}

Пшеница яровая - важная зерновая культура Нечернозёмной зоны России. Зерно пшеницы богато белком (16-24\%) и клейковиной (28-40\%), имеет отличные хлебопекарные качества.

Средняя урожайность зерна яровой пшеницы по России составляет 12-14 ц/га, при оптимальной её урожайности 25 ц/га, что связано с особенностями почвенно-климатических условий в основных районах её возделывания $[1,2]$. Условия Нечерноземья отличаются недостаточностью обеспеченности теплом и низким плодородием почв,

Системы удобрений, яровая пшеница, урожсайность

и качество, органоминеральный субстрат, минеральные удобрения

Fertilizer systems, spring wheat, the yield and quality, organo-mineral support, mineral fertilizers что является причиной выращивания этой культуры для зернофуражного применения.

В последние годы в Ярославской области наметилась тенденция к активному использованию сортов интенсивного типа яровой пшеницы, которые при высокой агротехнике способны формировать урожай качественного зерна с хорошими потребительскими свойствами.

Одна из причин низкой урожайности яровой пшеницы - отсутствие научно обоснованной системы применения удобрений. Известно, что яровая пшеница требовательна к почве из-за недостаточно развитой корневой системы и её невысокой поглотительной способности. Она хорошо растёт и развивается на почвах с мелкозернистой структурой, с высоким содержанием питательных веществ, слабокислых или нейтральных.

Создание оптимальных условий питания пшеницы путём разработки системы удобрений является важным условием для повышения урожайности и улучшения качества зерна.

Поэтому целью исследований было установить изменения показателей урожайности яровой пшеницы и качества её зерна под действием различных агротехнических приёмов, среди которых актуальным и значимым является изучение систем удобрений.

\section{Методика исследований}

Исследования проводились в 2018 году в посеве яровой пшеницы сорта Дарья в многолетнем трёхфакторном стационарном полевом опыте ФГБОУ ВО Ярославская ГСХА на дерново-подзолистой среднесуглинистой почве. Опыт был заложен методом расщеплённых делянок с рендомизированным размещением вариантов в повторе-

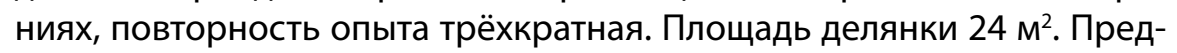
шественник - вико-овсяная смесь. Схема опыта: система основной обработки почвы (отвальная, поверхностная), система удобрений 
(без удобрений, использованная минеральная вата IZOVOL AGRO UNIVERSAL, органо-минеральный субстрат, обеззараженный куриный помёт $\mathrm{N}_{80} \mathrm{P}_{65} \mathrm{~K}_{40}$, органо-минеральный субстрат + минеральные удобрения $\mathrm{N}_{80} \mathrm{P}_{80} \mathrm{~K}_{80}$ минеральные удобрения $\left.\mathrm{N}_{80} \mathrm{P}_{80} \mathrm{~K}_{80}\right)$, система защиты растений от сорняков (без гербицида, с гербицидом).

В данной работе приводятся результаты по отвальной системе обработки почвы и четырём системам удобрений (без удобрений, органоминеральный субстрат, органо-минеральный субстрат + минеральные удобрения $\mathrm{N}_{80} \mathrm{P}_{80} \mathrm{~K}_{80}$, минеральные удобрения $\mathrm{N}_{80} \mathrm{P}_{80} \mathrm{~K}_{80}$ ) по фону без гербицида.

Минеральные удобрения под яровую пшеницу вносились под предпосевную обработку в норме $\mathrm{N}_{80} \mathrm{P}_{80} \mathrm{~K}_{80}$.

Куриный помёт вносился в 2017 году под предпосевную обработку в норме 41 ц/га, что в пересчёте составляет $\mathrm{N}_{80} \mathrm{P}_{65} \mathrm{~K}_{40}$. Влажность куриного помёта - $26,32 \%$. В сухом помёте содержалось 2\% азота, 1,2\% фосфора и 0,9\% калия.

Минеральная вата вносилась в 2017 году под предпосевную обработку в норме 20,8 ц/га.

Методика опыта общепринятая.

Урожайность яровой пшеницы учитывали сплошным поделяночным методом во всех повторениях опыта с пересчётом на абсолютно чистую продукцию и стандартную влажность зерна (14\%).

Статистическая обработка урожайности зерна яровой пшеницы проведена методом дисперсионного анализа [3].

Содержание азота в зерне пшеницы определяли по ГОСТ 13496.4-93 «Корма, комбикорма, комбикормовое сырье. Методы определения содержания азота и сырого протеина», содержание клейковины - по ГОСТ Р 54478-2011 «Зерно. Методы определения количества и качества клейковины в пшенице».

В 2018 году агрометеорологические условия для роста и формирования зерна яровой пшени- цы были в целом благоприятными, вегетационный период характеризовался как тёплый с достаточным выпадением осадков [4].

\section{Результаты исследований}

Урожайность является одним из основных показателей, подтверждающих состоятельность и привлекательность культуры для широкого внедрения в сельскохозяйственное производство.

При основном внесении минеральных удобрений их действие направлено на рост и развитие растений, на формирование урожая зерна и соломы. Применение минеральных удобрений в сочетании с органо-минеральным субстратом способствует улучшению питательного режима растений в период от колошения до конца молочной спелости зерна и повышению качества зерна.

В августе 2018 была проведена уборка урожая зерна яровой пшеницы в полевом опыте. Данные проведённых нами исследований представлены в таблице 1.

Наибольшая урожайность наблюдалась при использовании органо-минерального субстрата отдельно и в сочетании с минеральными удобрениями $\mathrm{N}_{80} \mathrm{P}_{80} \mathrm{~K}_{80}: 23,08$ и 20,17 ц/га соответственно. Прибавка урожая в этих вариантах составила 11,77 и 8,86 ц/га соответственно.

Результаты исследований показали, что применение органо-минерального субстрата как отдельно, так и в сочетании с минеральными удобрениями оказало существенное влияние на урожайность яровой пшеницы.

Абсолютный вес 1000 зёрен яровых зерновых культур в Ярославской области при стандартной влажности составлял 34,6-46,6 г [4]. Определение массы 1000 зёрен позволяет дать оценку запасов питательных веществ в семенах, то есть чем выше масса 1000 зёрен данной культуры, тем выше содержание в ней питательных веществ.

В нашем опыте масса 1000 зёрен оказалась наибольшей в варианте с применением органоминерального субстрата и составила 26,76 г.

Таблица 1 - Влияние систем удобрений на урожайность яровой пшеницы

\begin{tabular}{|l|c|c|}
\hline \multicolumn{1}{|c|}{ Вариант опыта } & Урожайность, ц/га & +/- к контролю \\
\hline Контроль без удобрений & 11,31 & + \\
\hline $\mathrm{N}_{80} \mathrm{P}_{80} \mathrm{~K}_{80}$ & 15,24 & $+11,77$ \\
\hline Органо-минеральный субстрат & 23,08 & $+8,86$ \\
\hline $\mathrm{N}_{80} \mathrm{P}_{80} \mathrm{~K}_{80}+$ органо-минеральный субстрат & 20,17 & 2,765 \\
\hline $\mathrm{HCP}_{05}$ & & \\
\hline
\end{tabular}


Исследования показали, что изменение питательного режима почвы при внесении удобрений оказывает влияние не только на продуктивность яровой пшеницы, но и на технологические качества зерна (табл. 2).
Содержание белка является важнейшим показателем хлебопекарных достоинств силы муки, пищевой ценности и её целевого использования.

Повышение общего содержания белка в зерне может быть достигнуто агротехническими при-

Таблица 2 - Влияние систем удобрений на качество зерна яровой пшеницы

\begin{tabular}{|l|c|c|c|}
\hline \multicolumn{1}{|c|}{ Вариант опыта } & $\begin{array}{c}\text { Сухое } \\
\text { вещество, \% }\end{array}$ & $\begin{array}{c}\text { Белок, \% на абсолютно } \\
\text { сухое вещество }\end{array}$ & $\begin{array}{c}\text { Количество сырой } \\
\text { клейковины, \% на абсолютно } \\
\text { сухое вещество }\end{array}$ \\
\hline Контроль без удобрений & 91,76 & 13,01 & 34,62 \\
\hline $\mathrm{N}_{80} \mathrm{P}_{80} \mathrm{~K}_{80}$ & 91,60 & 14,24 & 37,93 \\
\hline Органо-минеральный субстрат & 91,66 & 13,51 & 28,21 \\
\hline $\begin{array}{l}\mathrm{N}_{80} \mathrm{P}_{80} \mathrm{~K}_{80}+\text { органо-минеральный } \\
\text { субстрат }\end{array}$ & 91,96 & 16,44 & 39,34 \\
\hline
\end{tabular}

ёмами, исходя из некоторых сторон физиологии налива зерна. К началу налива зерна рост вегетативных органов заканчивается. При старении и отмирании этих органов часть накопившихся в них органических и минеральных веществ повторно используется колосом. Одновременно продолжают работать ассимилирующие органы и корневая система. Соотношение между этими потоками веществ, а также соотношение азотистых и безазотистых веществ в каждом из них определяет содержание белка в зерне полученного урожая.

Наибольшее количество белка в зерне яровой пшеницы (16,44\% в пересчёте на абсолютно сухое вещество) отмечено при внесении минеральных удобрений в сочетании с органо-минеральным субстратом, что выше контроля на 3,43\%.

В опыте прослеживается чёткая связь между содержанием в зерне клейковины и используемым видом удобрения. Как известно, клейковина определяет хлебопекарные качества пшеницы. Так называемая «сила» муки зависит в основном от состояния белкового комплекса и прежде всего от количества и качества клейковины. Содержание её резко изменяется в зависимости от сортовых особенностей пшеницы и условий её выращивания. Количество сырой клейковины в зерне пшеницы колеблется от 20 до 50\%. Поэто- му определение клейковины в зерне имеет важное значение [5].

Наибольшее количество клейковины (39,34\% в пересчёте на абсолютно сухое вещество) наблюдалось при внесении минеральных удобрений в сочетании с органо-минеральным субстратом.

\section{Выводы}

1. Внесение минеральных удобрений как отдельно, так и совместно с органо-минеральным субстратом, способствует повышению урожайности и улучшению качества зерна яровой пшеницы.

2. Максимальная урожайность зерна яровой пшеницы (23,08 ц/га) наблюдалась при использовании органо-минерального субстрата.

3. Наибольшее содержание белка (16,44\% в пересчёте на СВ) и сырой клейковины $(39,34 \%$ в пересчёте на (B) в зерне пшеницы отмечается на варианте внесения $\mathrm{N}_{80} \mathrm{P}_{80} \mathrm{~K}_{80}+$ органо-минеральный субстрат.

4. При относительно благоприятных погодных условиях на дерново-подзолистой среднесуглинистой почве в Ярославской области имеется реальная возможность выращивания зерна яровой пшеницы достаточно высокого качества, вполне пригодного для хлебопечения и производства кондитерской продукции.

\section{תumepamypa}

1. Милащенко, Н.3. Резервы производства высококачественного зерна пшеницы в российском земледелии [Текст] / Н.3. Милащенко, С.В. Трусикин // Земледелие. - 2018. - № 7. - С. 30-33.

2. Власенко, А.Н. Влияние сорта и технологии на эффективность возделывания яровой пшеницы в лесостепи Приобья [Текст] / А.Н. Власенко, Н.Г. Власенко, О.Г. Кулагин и др. // Земледелие. - 2018. - № 4. C. 15-19. 
3. Доспехов, Б.А. Планирование полевого опыта и статистическая обработка данных [Текст] / Б.А. Доспехов. - М.: Изд-во Колос, 1972. - 206 с.

4. Ярославский центр по гидрометеорологии и мониторингу окружающей среды. Обзор агрометеорологических условий за 2017-2018 сельскохозяйственный год по Ярославской области. - Ярославль, 2018.

5. Ненайденко, Г.Н. Качество зерна мягкой яровой пшеницы в областях верхней Волги [Текст] / Г.Н. Ненайденко, Т.В. Сибирякова // Владимирский земледелец. - 2017. - № 4. - С. 15-18.

\section{References}

1. Milashchenko, N.Z. Rezervy proizvodstva vysokokachestvennogo zerna pshenicy v rossijskom zemledelii [Tekst] / N.Z. Milashchenko, S.V. Trusikin // Zemledelie. - 2018. - № 7. - S. 30-33.

2. Vlasenko, A.N. Vlijanie sorta i tehnologii na jeffektivnost'vozdelyvanija jarovoj pshenicy v lesostepi Priob'ja [Tekst] / A.N. Vlasenko, N.G. Vlasenko, O.G. Kulagin i dr. // Zemledelie. - 2018. - № 4. - S. 15-19.

3. Dospekhov, B.A. Planirovanie polevogo opyta i statisticheskaja obrabotka dannyh [Tekst] / B.A. Dospekhov. - M.: Izd-vo Kolos, 1972. - 206 s.

4. Jaroslavskij centr po gidrometeorologii i monitoringu okruzhajushhej sredy. Obzor agrometeorologicheskih uslovij za 2017-2018 sel'skohozjajstvennyj god po Jaroslavskoj oblasti. - Jaroslavl', 2018.

5. Nenajdenko, G.N. Kachestvo zerna mjagkoj jarovoj pshenicy v oblastjah verhnej Volgi [Tekst] / G.N. Nenajdenko, T.V. Sibiryakova // Vladimirskij zemledelec. - 2017. - № 4. - S. 15-18.

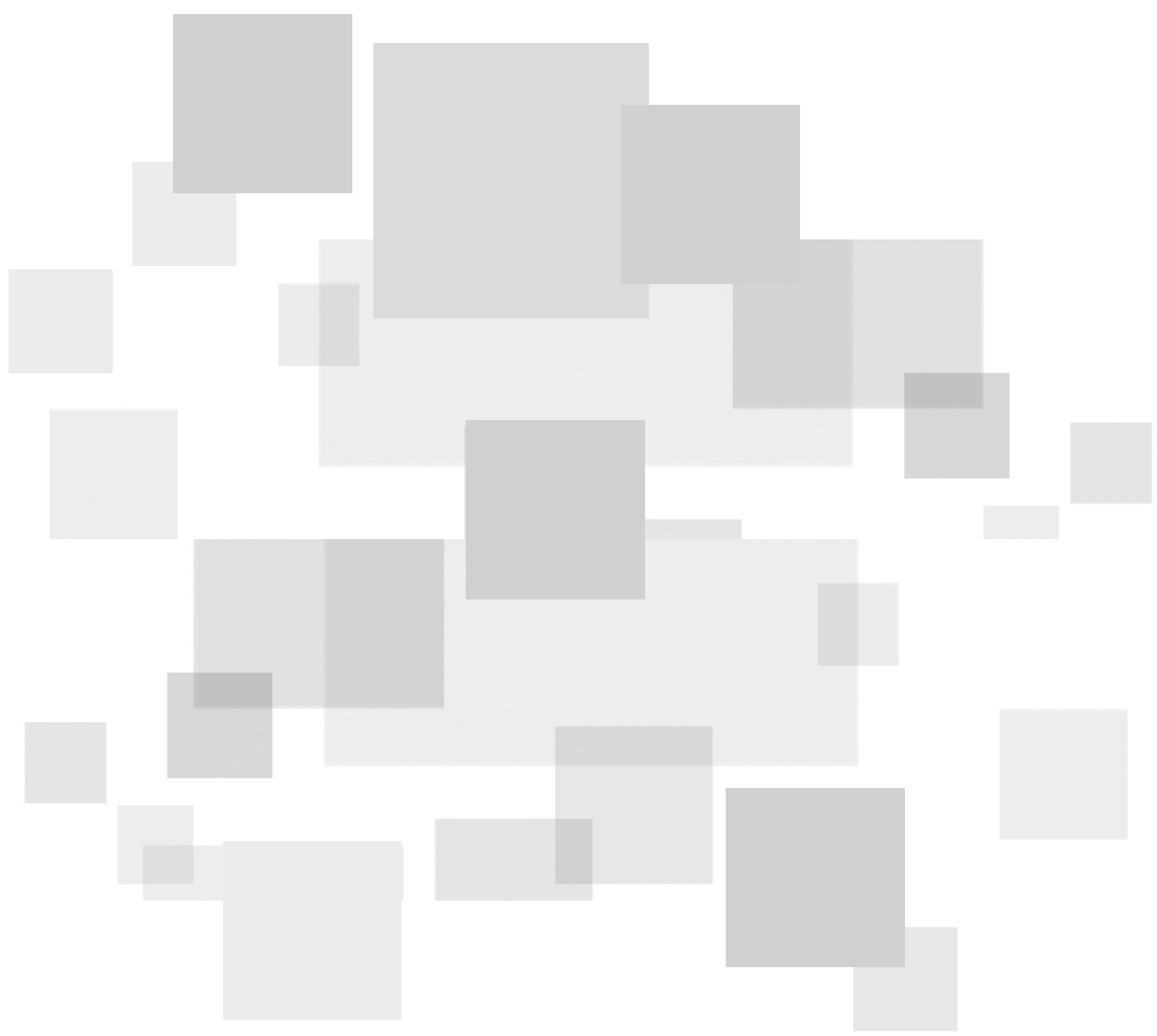

